\title{
Imperial Internationalism: The Round Table Conference and the Making of India in London, 1930-1932
}

\section{The International Making of States}

In 1919, two events in Paris and London reshaped the Indian world. The first was the signing of the Treaty of Versailles by representatives of India, which would-unexpectedly for Britain-make India a founding member of the League of Nations. The second was the granting of royal assent to the Government of India Act, instituting the political system called "dyarchy." This new system meant the devolution of powers to British Indian provinces, some of which would be administered by elected Indian ministers. Through these two events, India, first, acquired international subjecthood as a coherent diplomatic entity and, second, fragmented and dispersed its sovereignty into the provinces of British (not Princely) India. Both of these processes are relatively well known, and both show how "India" was making both a new inner and outer state. This was part of an historical moment in which international organizations were inserting themselves into the technologies of state-making in unprecedented ways-from the re-ordering of Europe at Versailles to the making and supervision of Mandated Territories that would follow at Geneva. ${ }^{1}$

What is less well appreciated are the contingencies beneath these parallel events in 1919 Paris and London. The Versailles treaty was signed on June 28, while the royal assent was not given to the India Act until December 23. As such, the India that signed the Paris treaty was not only a dubiously performative unity of British and Princely India; the constitution of British India was only legislatively formalized six months after the signing of the Paris Peace Treaty; therefore the signatory was even more fictional than is usually acknowledged. The second contingency arises from the first. The Paris Peace Conference consumed the energies of many leading British politicians for the first half of I9I9, precisely when the Government of India Bill was going through Parliament. ${ }^{2}$ These included the ex-viceroys of India Lord Curzon (1899-1905, acting as Foreign Secretary in 1919) and Lord Hardinge (I9II-I9I6, who headed the British Delegation in Paris). Curzon, especially, had been no advocate of the liberal reforms pursued by Edwin Montagu, Secretary of State for India, since the latter's declaration of 1917 that the aim of Indian constitution reform was eventual dominion status. ${ }^{3}$ Had these men not had their attention divided between London and Paris, would the Indian reforms have been passed in the form they did? These contingencies remind us to attend to the messy realities of both international diplomacy and the technologies of the state. It was the messiness of state-making, and nationalism forced dyarchy to be revisited within the decade.

The working of the I9I9 Act had proven so dissatisfactory to both Indian subjects and 
governors that a statutory commission, directed to review the act's first decade, was brought forward to I928. The all-white nature of the "Simon Commission," as it became known, led to such virulent protests within India that, before its recommendations had even been agreed upon, the British Government announced that representatives from British and Princely India and Her Majesty's British Government would meet in London for a "Round Table Conference" (RTC, November I2, I930 to January 19, I93I) to discuss India's constitutional reform. After a plenary session in which the agenda was set, the conference divided up into separate committees to consider core topics (federal structure, provincial constitution, minority communities, franchise, defense, and particular regions), assisted by a government secretariat, before reconvening to debate its conclusions. The largest nationalist party, the Indian National Congress (INC), had launched the civil disobedience movement in protest at the terms set for debate and boycotted the conference. It found that its demands for Dominion Status (defined by Motilal Nehru in I928 as responsible government and a degree of autonomy and self-representation within the empire, as enjoyed by Canada, Australia, New Zealand South Africa, and Ireland) were not met due to the conference's acceptance of the goal of a federal Indian, but not independent, state. ${ }^{4}$

Congress leader MK Gandhi was released from prison in order to attend the second session of the RTC (September 7, I93I to December I, 193I), to much fanfare, only to be arrested again on his return to India. Congress and most of the Princes did not attend the final session (November 17, 1932, to December 24, 1932) of the conference. After passing through parliamentary scrutiny, the conference recommendations were manifested in the Government of India Act (1935), which devolved powers to provincial, elected governments and set in place the procedures through which India could become a federal state. The conditions for these procedures to be activated were never met, so the federal state did not actualize until after independence, in 1947.

The sovereign technology of state-making at the RTC enables us to envision it as an international organization. It brought together representatives of different nations. It invoked international comparisons with the Dominions and the League of Nations, and, for some, the inspiration of radical anticolonial and socialist forms of internationalism. However, to the extent that it is considered in South Asian studies at all, the RTC is read as a moment of nation-making, of the consolidation of the centrality of congress nationalism, and of the solidifying of national religious divides. ${ }^{5}$ That is, although an international event, the RTC is assumed to mark the collapse of internationalism and the triumph of nationalism.

In this essay, I would like to suggest that we supplement these readings with continued attention on the RTC as an international organization, even if it was "imperial internationalism" that ultimately triumphed by incorporating anticolonial (inter)nationalisms. ${ }^{6}$ This argument is made in two stages. First, the influence of the League of Nations on the conference is examined, by considering its role as model, precedent, and potential arbiter, and by exploring the time conference delegates spent in Geneva. Second, the paper assesses the influence of internationalism at the Round Table meetings, in terms of the form of the conference and the content of some of the brands of internationalism articulated there. Before introducing Fred Halliday's typology of internationalisms, with which this paper critically engages, I briefly introduce the recent 
internationalist turn in South Asian studies_-and the emerging interest in conferences as vibrant political sites - that informs how I present the RTC as an international technology of state-making.

\section{International India}

Over the last twenty years, studies of colonial India (including, though with a lesser emphasis, those areas that would become post-colonial Burma, Pakistan, and Bangladesh) have taken an international turn. India's place within the imperial system, its "jewel in the crown" status, is widely acknowledged, as is its emergence into international diplomatic recognition during the 1914-1918 war. ${ }^{7}$ The broader significance of Indian technologies of the state and the military for securing the empire as well as the influence of its policemen within the broader "Indian Ocean Arena" have also long been acknowledged. ${ }^{8}$ If these studies marked India's reach beyond its national boundaries within imperial networks, further works have attempted to extract India from methodological nationalism (and imperialism) by telling its history beyond state-based and imperial geographical frames. ${ }^{9}$ These have included accounts of international scandals and their domestic effects regarding Indian sexual practices and legislation, of entanglements between India and Germany, and the influence of subaltern labor migration across the Bay of Bengal and into the Pacific. ${ }^{10}$ Prominent within these examples have been anticolonial thinkers and activists who exploited the international (as both an ideal and series of extra-national networks) for their own means, with the international functioning variously as an intrusive and judgmental externality, a source of inspiration and collaboration, or as a place for labor, profit, and campaigns for workers' rights. Others have focused on anticolonial internationalists, who reworked purportedly "western theories" (whether communist, anarchist, or humanist) to their own ends. ${ }^{11}$

A recent collection by Raza, Roy, and Zachariah reminds us just how many international blueprints there were in circulation, beyond the models of the League of Nations and the Communist International, for remaking the world in the aftermath of the First World War and the Bolshevik Revolution. Among those listed are pacifism, panIslamism and pan-Africanism, Aryanism, anti-imperialism, suffrage, romanticism, feminism, temperance, eugenics, and fascism: “Their divergent ends and objectives were held together, if temporarily, by a euphoria for the vastness and integratedness of the world and the desire and optimism to remake it and shape the future of humanity." 12 The editors acknowledge, however, that while nationalism cannot explain the trajectories of internationalism, many of the agents of internationalism they study viewed themselves as agents of national liberation; that is, that the internationalist moment in the interwar years was framed by the principle of nationalism. ${ }^{13}$

While this may be the case, Manu Goswami suggests that contemporary histories of internationalism are framed by a shared Euro-American narrative of failure, by turns one of moralizing judgment and regressive nostalgia. ${ }^{14}$ This has come to inflect views of interwar anti-imperial internationalisms that, she insists, were neither reducible to nor opposed to nationalism. What she calls colonial internationalisms "improvised a distinct future-oriented politics," and she calls upon us to write the histories of expectations as 
much as of experiences. ${ }^{15}$ Rather than recounting a separate history of a colonial or antiimperial internationalism, in this essay, I hope to suggest how radical and imperial internationalisms intersected within the liberal setting of the Round Table Conference.

The RTC marked a technology of the state in which imperialism and internationalism intersected. The most obvious and institutionalized space in which this also happened was in Geneva, through the League of Nations. For some, the League facilitated the ongoing colonial mapping of the globe through its Mandates Commission, precipitating crises of both empire and internationalism. ${ }^{16}$ For other writers and administrators who bridged the imperial and international spheres, such as Alfred Zimmern, Geneva was a space of hope, promising a "Third British Empire" that could flourish with and possibly through the League of Nations. ${ }^{17}$ If it was a place of hope for some liberal-imperial thinkers, the "Wilsonian Moment" had rapidly faded for anticolonial thinkers from Egypt and India to China and Korea, who found that self-determination would not be accorded to the subjects of empire. ${ }^{18}$

What these debates swirling around Geneva confirmed was that "internationalism" was (and is) what Fred Halliday called a "cluster concept," lacking a core meaning but with recurrent themes. ${ }^{19}$ These themes include beliefs that an objective process (predominantly economic/materialist) was driving internationalization; that, in consequence, political collaboration across national borders was increasing; and that these processes were morally good and desirable, promoting freedom, tolerance, and prosperity. However, speaking to his late-I980s world, but drawing upon historical examples and moments, Halliday asked, "Desirable for whom?” In response, he proposed three typologies of internationalism. "Liberal internationalism" is based on the optimistic approach that societies and individuals can cooperate to enhance peace and prosperity, an approach represented in this essay most clearly by the League of Nations. His second category, which challenges the first, is "hegemonic internationalism," which posits that world integration takes place on asymmetric, unequal terms (and that this could be a good thing). For Halliday, and for us, this approach is represented by the British Empire and what we can call its "imperial internationalism." The third concept, of radical or revolutionary internationalism, challenges both liberal and imperial forms. The most famous example is Marx's proletarian internationalism, but Halliday also listed radical republican, anarchistic, revolutionary, and Islamic internationalism; anticolonial nationalists represented the most radical internationalists at the RTC. ${ }^{20}$

The point, however, is that in the messy realities of the interwar world, these analytical categories quickly broke down. While "die hard" conservative imperialists attempted to kill off substantive constitutional reform, they were external voices to a conference mostly dominated by liberal imperialist views of India's place within an imperial and internationalist future. ${ }^{21}$ While the conference welcomed over 150 Indian delegates, they were mostly selected because they were moderate, not radical, anticolonialists who viewed India's international future as within the empire, for the time being. ${ }^{22}$ And while liberal internationalists participated (as politicians, commentators, and experts), they fully accepted the realpolitik of Britain's need to consolidate, or at least hold, its grip on India. ${ }^{23}$ Indeed, the RTC assumed the form of liberal internationalism (the international 
conference) and used it to bring together imperial and anticolonial delegates to thrash out, over 193 days during three sessions, a national and international future for India.

Therefore, Halliday's ideal types present useful ways with which to explore the structural differences between types of internationalism that, in practice, intersected and hybridized. In this paper, the conference will be treated as a valuable space for understanding these intersections via knowledge creation, public performance, legitimation, and protest. ${ }^{24}$ This allows us to think about the historical geographies of internationalism: its spaces and networks; the specific performances of internationalism's abstractions; and the way internationalism intersected with political projects; namely, here, the crafting out of an interwar state for India. ${ }^{25}$ The question to be pursued is: to what extent was this crafting an international crafting? How did international organizations and the expectations of internationalism craft India through the RTC (or not)? These two questions structure the partial answers below, regarding the influence of the League of Nations on the RTC and rival internationalisms at the conference.

\section{The League of Nations and the Round Table Conference}

After Versailles, India became a founding member of the League of Nations. While League members included Dominions of the British Empire, India was the only non-selfgoverning member. ${ }^{26}$ The British government monitored India's communications with Geneva, while the Government of India successfully mobilized India's supposedly exceptional status (whether in terms of tropical embodiment, under-development, or political immaturity) to keep the League's formal enquiries, and its interpretations of internal law, out of the subcontinent. ${ }^{27}$ At the RTC, however, the League's liberal internationalism was taken up in new and often unexpected ways by advocates of both imperial and anticolonial internationalism. Here, we can see the League being appealed to as model, as precedent, and as arbitrator; in all cases, but to different extents, these appeals failed. Where the League perhaps exerted its largest influence-though hardest to trace-was by the lakeside in Geneva itself, where dozens of delegates had learned the art of internationalism first hand.

\section{Model}

In terms of international "conferences," the late nineteenth century had seen diplomatic congresses joined by an increasing number of scientific meetings that were designed to solve the logistical, technical, or epidemiological challenges of an increasingly globalized world. While lacking the political clout of diplomatic congresses, the technical conferences established international institutions to coordinate their meetings and pursue their objectives. ${ }^{28}$ The interwar years saw a profusion of new international conferences, augmenting the materialist and political processes of technical and diplomatic meetings with what Halliday termed the moral processes, and problems, of the new liberal internationalism: for instance, refugees, disarmament, anti-vice campaigns, and the trafficking of women and children. Many of these campaigns were taken up by the League of Nations through the various committees of its social and technical sections. ${ }^{29}$ While these committees achieved much, the League also had a pervasive influence through its nondirect interventions: the way it changed the tone of debates, the statistics and facts it publicized, the educational materials it provided, and the vocabularies it established; in 
short, the way it established norms and acted as a model of what Halliday termed liberal internationalism. ${ }^{30}$

The League acted, alongside affiliated bodies like the International Labor Organization, as a model not just through what it did, but also how it did it. ${ }^{31}$ The international relations and legal scholar Frederick Sherwood Dunn suggested, in 1929, that the profusion of international conferences in the last ten years could be divided "up between conferences of the League or of its various organs, conferences convened by the League and held under its auspices, conferences initiated by the League but not convened by it or held under its auspices, and conferences not connected with the League at all." ${ }^{32}$ The League came to dominate the field of international conferencing because it, itself, "was intended by its authors to be a permanent system of international conferences for the purpose of dealing with political matters from the standpoint of the entire international community as a whole." ${ }_{33}$ Geneva functioned as a near-constant conferencing city, with its various committees calling in representatives from around the world on a periodic basis. This fast worked to establish the League's way of doing internationalism as a model.

The RTC in London sat along a clear and established lineage of British imperial conferences, of which there were twelve between 1887 and $1937 .{ }^{34}$ It was immediately preceded by the 1930 Imperial Conference in London, at which the foundations for the modern British Commonwealth were laid, such that when Indian delegates for the forthcoming RTC_-including the war veteran Maharajah of Bikaner-laid wreaths at the Cenotaph as part of the Armistice Day commemoration on Sunday November 9, they did so alongside the Dominion prime ministers. ${ }^{35}$ But the India conference was not an Imperial Conference (see later), and it bore the distinct mark of League organization. On September 23, 1930, during the run up to the RTC, the Conservative Party Delegation's secretary, Robert J. Stopford, wrote to Tory delegate and Party Treasurer Sir Samuel Hoare that: "Carter tells me that he $\&$ his staff will form the Conference Secretariat-available for the use of all delegates, like the League of Nations Secretariat $-\&$ that the combined British Delegation will have a Secretariat of their own consisting of Dawson of the India Office (a first rate man) with one Indian \& one English ICS [Indian Civil Service] assistants." 36

Archibald Carter had been appointed the Secretary-General (also the title of the leader of the League) of the RTC and oversaw its design and every day running. The Conference was provided with a Secretariat that, again, mirrored the League's "Permanent Secretariat," which functioned as its civil service, although the "The Central Secretariat" was also the name of the headquarters of the Indian Civil Service in New Delhi. Carter answered to an advisory committee of the British Government's India Office, while his staff were divided into a hospitality committee, press department, finance committee, and those concerned with the conference directly, who assisted the rapporteurs of the committees and subcommittees in drafting their reports. ${ }^{37}$

Although rarely acknowledged publicly, the influence of the League over the terminology and machinery of the RTC was noted at the very highest-level meetings in the run-up to the conference. The "Secret Notes of the Indian Round Table Conference British Delegation Government Members Meeting" at Io Downing Street on October Io, 1930, recorded Secretary of State William Benn, suggesting that on day two of the conference an Indian Prince should nominate the prime minister, Ramsay MacDonald, as 
chairman: "On being elected Chairman, the Prime Minister would propose that a Bureau (to adopt a League of Nations name for a Standing Orders or Business Committee) should be set up." 38

The influence of the League model did reach its limits, however. While many of the League meetings were open to the public, within the first few days of the RTC plenary session, the delegates had agreed that the conference should be held in private, due to the political and religious sensitivities to be discussed, in the context of the ongoing Civil Disobedience movement in India. ${ }^{39}$ The precedence of the Imperial Conferences, in addition to those of the League, were also followed, while the British Government insisted that it would not treat the RTC as a League conference in London, especially when it came to paying the costs of its delegates. G. S. Bajpai, Secretary of the British India delegation, had applied for the same grant to cover his travel expenses from India as the delegates, on the basis that his previous visit to Geneva had been paid for that way. The parallel was very quickly put down by the India Office, which insisted, on December 5, I930 that: "The Round Table Conferences is not a League of Nations' Conference or the Imperial Conference. It is unique. It was decided from the outset that officials from India attending the Conference, whether as Advisors or a Secretaries, should do so on deputation terms." ${ }^{40}$ In terms of formal bureaucracy, then, imperial rather than liberal internationalism marked British policy. But the latter also worked through influence, norm, and precedent.

\section{Precedent}

If the League inspired the model of the RTC then it also made occasional appearances on the RTC stage as a precedent that could be cited in favor of certain claims on the international stage. Here, it functioned not as a deus ex machina - it did not appear itself-but as an off-stage referent. As noted earlier, India had signed the Treaty of Versailles when its domestic constitution was not yet completed and when its capacity to sign international treaties was, at best, in question. Nevertheless, it had functioned for over a decade in Geneva as a unitary state and, for some delegates, this was proof enough that a federal India could unify the formally distinct Princely States and British Indian Provinces. ${ }^{41}$ In this sense, the League in Geneva functioned as a technology of the state: it allowed an internally divided sovereign body to function in the international sphere as if it were a singular and coherent form. Referencing this precedent directly on September 17, I93I, within a Federal Structure Committee meeting during the second session of the RTC, the Bengal liberal delegate, Sir P. C. Mitter, insisted that if the object of federating was to increase the strength of the Indian Motherland, then:

Let us suppose a representative of India goes to the League of Nations under present conditions, and let us suppose that a representative of India goes to the League of Nations in future, representing a federated India. Cannot that latter representative hold up his head much higher than any representative, however exalted, however able, however truly representative he may be, who goes at the present moment? ${ }^{42}$

On September 14, 1931, Congress supporting Delegate Mr. A. Rangaswami Iyengar had gone further, referencing international relations more broadly in the same committee. $\mathrm{He}$ 
pointed out that there was a precedent for India being accepted as a self-governing and united "external personality" in "international transactions":

We British Indians and Indian States, to all intents and purposes, present the appearance of a united and self-governing India to the outer world in regard to transactions connected, for instance, with the League of Nations, with the Imperial Conference, and various other institutions in which, so far as the theory of representation is concerned, India is treated as a member of the British Commonwealth to which we all belong. Whether we shall become free and equal partners in the Commonwealth is the problem which we are going to solve at the sittings of this Committee. ${ }^{43}$

The force of Iyengar's argument was undercut, however, by the hemming in of his claims and by a misunderstanding of the internationalism of the RTC's, and his committee's, interests. He admitted to only talking about a "theory of representation"; namely, that India might be perceived as acting unitarily at the League, but that this allowed Britain to control India's representation at Geneva. And, secondly, the idea that India's international position within the Commonwealth was up for debate at the RTC, and especially in the Federal Structure Committee (established to confirm the future internal structure of the Indian state), was out of the question. Speaking on September I5, the Hindu representative and Gandhi advisor Madan Mahan Malaviya went beyond India's representation to the reality of the negative precedent set by the imperial internationalism in which it was situated. He admitted that if India were granted full selfgovernment it might find international parity with the dominions. Yet, he noted that although India's contribution to the war effort had been praised by prime ministers and viceroys alike:

One would imagine that, after such utterances, India would be placed on a footing of equality with the self-governing Dominions of the British Empire. India was indeed made an original Member of the League of Nations, but that was a sort of comedy that, not having freedom to govern itself, India should be called on to take part in the discussion and decision of affairs affecting the freedom of other countries, was somewhat incongruous. But this is by the way. ${ }^{44}$

While India's role in it might have been considered peculiar, the League itself was not, yet, widely considered by Indians to be a joke or solely a white man's club (a view that would spread after the Italian invasion of Abyssinia in 1935). In the early I930s, there were still those in India who felt that it should appeal to the League to consider colonial injustices. ${ }^{45}$ The Hindu Mahasabha delegate Dr. B. S. Moonje, for instance, still had faith in the League and went beyond calling on precedence to actually suggest the League act as arbitrator (that is, not as abstract precedent but as a body that could intervene in Indian affairs).

\section{Arbitrator}

Moonje was a divisive figure and explicitly viewed his role as defender of the Hindu community from the supposedly better-organized and better-disciplined Muslim delegates, 
and their claims to a greater number of seats in provincial legislative assemblies under the proposed constitution. Throughout the first session of the RTC, he insisted that if the British granted dominion status to India then the "communal" question would be solved by Hindus and Muslims themselves. In a meeting with Benn on December 5, I930, recalled in Moonje's personal diary, the Secretary of State for India apparently suggested that Moonje put his case to obstructionist Conservative politicians to settle, or "better still," to hand the matter over to the League of Nations for arbitration. ${ }^{46}$

Whether this planted the seed in Moonje's mind is unclear, but he raised the issue with the prime minister himself on December 9, when he was called to a private meeting alongside leading Hindu, Muslim, and British government representatives. ${ }^{47}$ MacDonald said he needed a proposal on the communal question for the delegates to take back to India after the first session of the RTC concluded. Moonje insisted that an offer of full responsible government and dominion status would do, but when this was not forthcoming Moonje suggested that the League of Nations be brought in to arbitrate. When both the Hindu and Muslim delegates laughed at the suggestion, Moonje asked what the League was for, if not to settle disputes? MacDonald was suggested as a conciliator between the implacable communal representatives, but Moonje insisted if this did not work then the League should be called upon to arbitrate. Moonje went on to launch a sustained, if ultimately unsuccessful, attempt to introduce the authority of League liberal internationalism into the imperially regulated internationalism of the RTC.

Moonje spent the following Sunday preparing a document proving that the League had helped solve the "minority problem" (of ethnic populations affected by border changes) in Europe. On December 25, he met the Indian poet and campaigner Rabindranath Tagore in London, who implored him to meet Muslim demands, but apparently agreed to sign a petition in support of League intervention should no agreement be necessary. ${ }^{48}$ Sir Malcolm Hailey, reporting on a Minorities Sub-Committee on January I, I93I, noted that Moonje had mentioned a pamphlet on the League (possibly the one he composed). Yet, Hailey explained, "The latter, of course, allows protection of minorities to the extent only of providing for their cultural interests and does not go to the extent of giving them separate representation. He [Moonje] claimed that since India belongs to the League of Nations she should follow the same principles." ${ }^{49}$ The Government of India would make it very clear in the following years that no League arbitration would be allowed in domestic matters, in accordance with article 15 , paragraph eight of the League covenant, but Moonje was unaware of this and continued his campaign for League intervention into the conference.

Between the first and second sessions of the RTC, Indian delegates returned to India to continue their conference investigations. On January 3I, I93I, Gandhi was released from jail and began negotiations regarding the suspension of Civil Disobedience and Congress participation in the RTC. On May I7, 193I, Moonje met Gandhi and other RTC delegates in Simla, the summer capital, where the latter insisted that Hindus must grant all Muslim demands, as the British would not take a divided India seriously..$^{50}$ Moonje recorded in his diary that he refused this "surrender" and that his Hindu Mahasabha (Society) proposals were fair and "met world standards," comparing favorably to those set by the League of Nations, whom he again suggested as arbitrators. Marking a rejection by both imperial and anticolonial internationalism of Moonje's appeal for liberal arbitration, Gandhi flatly 
refused. He suggested that it would be a humiliation to admit India could not solve its communal problem and would need the help of the League; better to boycott the RTC entirely.

Neither of them did, and Moonje got to put his League arbitration suggestion to Gandhi again in London on November 4, 1931, in opposition to the latter's support of government arbitration. Ten days later, Malaviya was pushing Moonje to accept MacDonald as arbitrator, suggesting that no one would agree to the League in this role. Moonje made a last pitch, offering that involving the League would get world opinion on to the Indian side, making the government unable to say no or to accept the intervention of the League, thereby forcing it to make a deal. Gandhi refused and, eventually, Moonje relented, agreeing to sign the request that MacDonald arbitrate himself.

With Gandhi's attempts to reconcile Hindus and Muslims concluding, in his words from the Conference, "with deep sorrow and deeper humiliation . . . [in] utter failure," the second session of the RTC concluded and Gandhi departed the UK. ${ }^{51}$ Before returning to India, he completed a short European tour, taking in Paris, Rome, and Geneva, arriving at the latter on December 6, I93I. He gave a public talk to an audience of 2,000 at the Victoria Hall and was visited by Albert Thomas of the International Labor Office (ILO). In Geneva, Gandhi stayed at Villa Olga, home to the author of his biography, Romain Rolland. Gandhi's British police guard reported that a number of "private conferences" took place at the villa, at which Rolland attempted to convince Gandhi of the merits of the Soviet system, without success. ${ }^{52}$ An anticolonial nationalist in the headquarters of liberal internationalism being wooed by socialist and Soviet internationalists may have been a sign of Gandhi's unique appeal. ${ }^{53}$ But Indians were not unknown in Geneva, nor were many of the RTC delegates. These personal connections provides the final thread connecting the League and the RTC.

\section{Lakeside Internationalism}

The League of Nations has been shown to have functioned as a model and as a referent that influenced the RTC, but it also influenced it as a place. Geneva functioned as a synecdoche for the League, becoming a symbol of ire to opponents of liberal internationalism and a heady utopia to its advocates. ${ }^{54}$ But Geneva also functioned as a thriving capital of internationalism, providing its accommodation, its infrastructure, and its laborers. ${ }^{55}$ Across all three delegations and from the highest ranked to some of the lowest, Geneva had featured in the biographies of RTC attendees: a place where they had learned the shared crafts of internationalism, of the conference, and-that newly vital hybrid - the art of international conferencing. The prosopography below must be relatively fleeting and incomplete, but it gives a sense of the bio-geographical internationalism of the RTC and the diversity of characters who experienced the lakeside internationalism of Geneva. ${ }^{56}$

In terms of the British Delegation, MacDonald himself was no stranger to Geneva, having made a visit in 1924 in his first term as prime minister where he co-proposed the Protocol for the Pacific Settlement of International Disputes; he would also attend disarmament conferences in 1932 and 1933. Sir Samuel Hoare, the Conservative Party Secretary of State for India (193I-1935) had been Deputy High Commissioner of the League of Nations for Care of Russian Refugees in I92I, while fellow Tory delegate Walter 
Elliot was a British delegate to the League in 1928. The liberal delegate Lord Lothian had been an early and influential supporter of the establishment of the League, while fellow liberal Graham White had been a member of the British League of Nations Union Executive Committee in 1923-1924 and 1930. The ICS officer Sir Geoffrey Corbett, acting as British Delegation Secretary at the RTC, had himself represented India at various international conferences, including the League of Nations Assembly and the ILO in I929. Similarly, the RTC publicity officer, George F. Steward, had been a member of the British delegation to League assemblies and conferences from 1924 to 1930. British RTC delegates, from politicians to officials, from Labour to Liberal and Conservative, had widely benefitted from experiences at Geneva.

The academic and adviser L.F. Rushbrook Williams also acted as a substitute delegate at the League Assembly in 1925, but he was substituting the Maharaja of Patiala, not a British delegate. At the RTC, he functioned as an advisor nominated by the Chamber of Princes; the "Indian States" had thirteen members of delegation staff, three of whom were English. This spoke to many of the intimate and (to some, disconcerting) aristocratic interconnections between the Indian and British landed elites, but princes of very different ranks had experience at Geneva.

The tradition of sending one British Indian and one Princely States representative to the League each year had built up a rich body of experienced men (they were all men) within Princely elite. Rushbrook William's employer, the Maharaja of Patiala, who attended the first session of the RTC, could still claim to have represented India at the League in 1925 but this faded in comparison to the record of his great rival, the Maharaja of Bikaner. Having signed the Treaty of Versailles, Bikaner had led the Indian delegation in 1924 and 1930, before heading from Geneva to London to represent India at the Imperial Conference, at the Cenotaph service, and then at the first two sessions of the RTC. The Maharaja of Kapurthala had represented India in the Assembly in 1926, 1927, and 1929, before attending the second session of the RTC. The Maharaja of Nawangar twice represented India in both Geneva and London, while the Maharao of Kutch represented India at the 192I League Assembly and the 193I second RTC session. Other members of the Indian States delegation staff also had, or would later accrue, experience in Geneva. Sir P. Pattani, was a member of the Indian delegation to the 1932 League Assembly; V. T. Krishnamachari, after attending the second session of the RTC, served the League Assembly in 1934 and 1936; while Sir Mirza Ismail, after attending the first two RTC sessions, led the Indian delegation to the Java Rural Hygiene conference, organized under the auspices of the League, in 1937.

Within the British Indian delegation there was also rich experience, both Hindu and Muslim. The Hindu Moderate delegates at the first two RTC sessions, V. S. Sastri and Sir Ramasawamy Aiyar, had represented India at the League assembly in I92I and 1926-1927, respectively. The aforementioned delegation staff member G. S. Bajpai had advised the Indian League delegation in 1929 and 1930, while Rao Bahadur Sir A. P. Patro, who represented the Justice Party at all three RTC sessions, also represented India in 193I. Muhammad Zafarullah Khan, a Muslim delegate for the first two London sessions, represented India at the League in 1939, at the end of its life; before this, the Aga Khan, the leader of the Shia Ismaili community who represented Muslims at all of the RTC 
sessions, was granted the role of president of the League Assembly in 1937. Yet, as Gandhi's meetings in Geneva had suggested, it was not only the home of liberal internationalism.

Sir Bhupendra Nath Mitra, delegate to the first RTC session and then High Commissioner for India in London from 1931, led the Indian delegation to the International Labor Conference in Geneva in 1932, while in 1937 (the by then, Sir) H. P. Mody, an industrial representative at the first two RTC sessions, served as an employers' delegate at the same conference. By far the most dedicated link between the RTC and socialist internationalism was, however, not that of a wealthy industrialist but of the trade unionist N. M. Joshi. He attended all RTC sessions as a trade union representative but had also been nominated by the Government of India to represent labor interests at the ILO in Washington in 1919, and then at Geneva in 1921-1922, 1925, 1929, 1934, and 1947. Seemingly the man with the most experience of Geneva, Joshi's motivation was more international workers' rights than anticolonial nationalism (see below).

This section has shown that the RTC was established, in part, on the model of the League of Nations, that it was appealed to as precedent and arbiter, and that it had trained many of the London delegates in the art of international conferencing. These included British men from all the main political parties, low and high Indian princes, Indian Hindus and Muslims, and representatives from high industry and grassroots unions. It remains to be seen, however, how internationalist the Round Table Conference sessions, and their outputs, actually were.

\section{International but not Internationalist?}

\section{The "Conference Method"}

While the following section focuses on how internationalist the RTC was, there are also doubts over the extent to which it should be regarded as an international conference at all. This could be because it was too imperial a conference. Imperial conferences are not typically considered international conferences, and were not listed in standard works on the subject. In Dunn's 1929 book, conferences were divided into League or non-League, political or nonpolitical, bargaining or legislative, and diplomatic or technical. While conferences between empires (Vienna I8I5, Berlin I885-1886) and nations (the Hague I899 and 1907) were listed, those within empires were not. ${ }^{57}$ The work of Norman Hill, referenced by Dunn, likewise divided international conferences into those of peacetime, the League as well as permanent, semi-public, and private organizations; he made no mention of imperial gatherings. ${ }^{58}$ Similarly, a database compiled from the League of Nations Archive lists 27I international conferences as taking place between the Versailles Peace Conference of 1919 and the First Session of the United Nations General Assembly in 1946; the six British imperial conferences that took place during this period are not mentioned, nor are the three sessions of the RTC. 59

The Round Table Conferences are not, however, recorded as imperial conferences either. India was represented at the imperial conferences but the RTC was not classified as imperial. Being organized by the British Government within one part of its empire, it was more of a colonial (or national) affair. Neither international nor imperial, the RTC has been filed under constitutional history. But its imperial significance could not have been greater, charged, as one influential author put it, with Holding India to the Empire. ${ }^{60}$ How 
might we appraise the international nature of the RTC as a state-making organization, beyond the influence of the League of Nations?

Even authorities like Dunn and Hill struggled to define and mark out set criteria for what an "international conference" was, but they set out various systematic forms of international conference organization and procedure that had emerged. The RTC as it actually functioned met most of these, not least aiming for one of Dunn's chief criteria, namely "the accomplishment of desired international regulation within the existing framework of established ideas and perceived social needs." ${ }^{61}$ This regulation was, however, of India by Britain. Despite its incorporation of "private" individuals making it, in Hill's terms, "semi-public," the RTC still most firmly met the criteria for a public conference: "When an assembly is convened and supported through the instrumentality of governments, and is composed solely of delegates officially chosen, it is in every sense public."62

In terms of Dunn's work, like international conferences, the RTC did not conform to any predetermined rules, starting "de novo," although the acceptance of the invitation was taken to also be an acceptance of the resulting agenda. ${ }^{63}$ It was malleable to the objectives jointly set out by the British and Indian governments; as Dunn put it, "The conference method is itself nothing more than a tool for achieving desired substantive ends." ${ }^{64}$ The RTC fits into Dunn's international conference categorizations (of administration) as "nonLeague" and (in terms of method) targeted at legislation rather than bargaining on set terms. But just as Dunn rejected the total distinction of political and nonpolitical as well as diplomatic or technical conferences, the RTC included seasoned diplomats as well as delegates with technical expertise, while it also addressed politically international issues (the relations between states) as well as notionally nonpolitical international concerns (India's role in, for instance, international commerce, transportation, and communications). ${ }^{65}$ And, in procedural terms, it followed the method set out most systematically by the League, as previously shown: having an initiator and organizing center; following the new international model of including state and nonstate representatives as well as those from smaller-scale, local organizations or communities; having a loose agenda that was devised during the conference plenary sessions; having attendees, including delegates, observers, secretaries, and advisors; and participating in discussions that were recorded verbatim - many of which were printed-despite most sessions not being open to the public. The conference resulted in an Act of Parliament, yet this act embodied a relationship between what was explicitly viewed as an imperial core and a colonial periphery, not a relationship between international dominions.

\section{The Conference Object}

Had the RTC ever, therefore, had an internationalist objective, rather than just an international method and form? If, as Dunn had it, the aim of an international conference was "the accomplishment of desired international regulation" then, at a superficial level, one could say it had. ${ }^{66}$ On October 31, 1929, Viceroy Irwin had clarified that implicit within Montagu's 1917 Declaration (with which this paper opened) was the assumption "that the natural issue of India's constitutional progress as there contemplated was the attainment of Dominion status." ${ }^{67}$ R. P. Singh has traced the complex lineage of these claims. ${ }^{68}$ As early as 1905 , in reaction to the administrative partition of the province of 
Bengal, Congress had called for a system of self-governance internationally comparable to that enjoyed by the Dominions. The government did not concede; but, in I9II, when reversing Curzon's partition of the province of Bengal, it proposed devolving powers to create administrations "autonomous in all provincial spheres." This call was taken up in modified form by Lord Hardinge during the war, marking political reform as a domestic not international concern. ${ }^{69}$

Montagu, the new secretary of state in 1917 , pushed for a declaration recommending Indian "self-government" within the Empire, but cabinet revisions led by Curzon reduced it to the declaration of "responsible government." The constitutional fudge of dyarchy pleased very few, and soon Congress demands for full dominion status were being repeated. The future governor of the Punjab and the United Provinces Sir Malcolm Hailey insisted in 1924 that responsible government need not mean dominion status (that is, an unrestrained legislature), leading to more forthright Congress demands for full dominion status in the Nehru report of 1928 . Here, responsible government and dominion status were set to mean the same thing. In making his statement in October 1929, Irwin was siding with the Congress interpretation (although he would send Hailey to the RTC's first session as a consultative official). Irwin's statement was seized on by many Indian nationalist delegates, such as M. A. Jinnah (who would become the first president of Pakistan after leading the Muslim League in the 1940s) during the opening speeches of the first day of the conference on November 12, 1930. He reminded delegates that the viceroy had clarified the British government's position in stressing that the "natural issue of India's constitutional progress was Dominion Status." ${ }^{70}$ Dominion status, however, quickly dropped out of sight at the RTC. The question, therefore, becomes: did other strains of internationalism survive at the conference?

\section{Internationalisms}

In a recent edited collection, Glenda Sluga and Patricia Clavin implore us to focus on the diversity of voices, sources, and approaches that can help us re-think twentieth century internationalism, calling attention to the "uneasy alliances and unlikely fellow travellers across the conceptual borders of nationalism and internationalism, and a broader spectrum of international thought and action." ${ }^{11}$ Cross-cutting the variants of internationalism suggested by Raza, Roy, and Zachariah, the collection features chapters on religious, socialist, feminist, capitalist, fascist, and indigenous internationalisms. All of these intersect in uneasy and unlikely ways with Halliday's typologies of liberal, hegemonic, and radical internationalism. The RTC presents a fascinating site in which unlikely and uneasy alliances between types of internationalism emerged and through which imperialism emerged triumphant over radical internationalisms, in large part, by using the liberal form of the conference to focus the debate on federalism as a channel for Indian nationalism. But this does not mean that the conference did not feature other forms of internationalism.

Some forms of internationalism at the RTC were well established but also, arguably, on the wane. Just like the League of Nations and dyarchy, modern pan-Islamism had been born of the First World War. The Treaty of Sèvres, as part at the Paris Peace Conference, and its treatment of the Turkish Caliph prompted the pan-Islamist Khilafat movement in the early 1920s. ${ }^{72}$ Two of its most forthright representatives in India had been the Ali brothers, who became vigorously targeted by the colonial government after Gandhi took 
up the Khilafat cause in the name of both anticolonialism and Hindu-Muslim unity. Following the founding of the modern Turkish republic and the suspension of Gandhi's Khilafat-supporting Non-Cooperation movement in 1922, support for the Pan-Islamism in India faded.

The Ali brothers were invited as Muslim delegates to the RTC_Maulana Shaukat Ali to the second and Maulana Mohammad Ali to the first. Mohammad Ali had rejected Congress in favor of the Muslim League but his pan-Islamist internationalist vision spoke less and less to the communal nationalism of the League. The RTC Muslim delegation's dealings with the British and "Hindu" delegates were led by the Aga Khan, Jinnah, and Sir Muhammad Shafi, though Ali proved a dedicated networker and rhetorician. His plenary speech on November 19, I930, dwelled on his ill health, recalled his visit to England in 1920 as part of a Khilafat Delegation, and proposed a federal India ("a Free and United States of India") but insisted that it should be formed not through dominion status within the Empire but through complete independence. ${ }^{73}$ This was, however, part of a radically internationalist, not nationalist vision:

I belong to two circles of equal size, but which are not concentric. One is India, and the other is the Muslim world ... We [Mussalmans] belong to these two circles, each of more than 300 millions, and we can leave neither. We are not nationalists but supernationalists, and I, as a Mussalman, say that "God made man and the Devil made the nation." Nationalism divides; our religion binds. No religious wars, no crusades, have seen such holocausts and have been so cruel a[s] your last war, and that was a war of your nationalism, and not my Jehad. ${ }^{74}$

During his speech, Ali also pointed out that Irwin had affirmed Montagu's I9I7 view of India's trajectory, rejecting the 1924 view of Hailey, whom he was glad to acknowledge at the conference that day. Hailey was writing regular conference updates to Viceroy Irwin in Delhi, and on January I, I93I, he wrote that Ali had taken ill and gathered a series of delegates around his bed to give them "a dying speech of some duration. He must have enjoyed himself immensely" although, he quipped, he doubted the audience had shared in the enjoyment. ${ }^{75}$

Five days later, Hailey had to write to the viceroy retracting his witticism: Ali had died on Sunday January 4. As part of his plenary address on November I9, Ali had insisted he would only return to India with the "substance of freedom" in his hand: "I would even prefer to die in a foreign country so long as it is a free country, and if you do not give us freedom in India you will have to give me a grave here." ${ }^{76}$ In the event, Ali's body was dispatched, after evening prayers at Paddington Town Hall conducted by the imam of the mosque at Woking, to Jerusalem. There the Grand Mufti of Palestine arranged a burial within the precincts of the Haram-al-Sharif, in a room facing the Dome of the Rock. ${ }^{77}$ While his brother would attend the second RTC session, when Maulana Mohamed Ali departed the conference so did its main driver of Islamic internationalism.

Just as Geneva was the home of both the League of Nations and the International Labor Organization (both of which emerged out of the Versailles peace conference), so labor internationalism (alongside liberal internationalism) was represented at the RTC in London. The history of socialist internationalism is rich and contested, its historiography 
stringing together congresses and conferences, movements and protest, ranging from communist revolutionaries to trade unionists and liberal campaigns for workers' rights. ${ }^{78}$ While M. N. Roy debated the colonial question with Lenin and attempted to bring a more radical communism to interwar India, the RTC certainly had no place for this internationalism. ${ }^{79}$ Rather, industry was represented by delegates like H. P. Mody and G. D. Birla, while the trade unions were represented by N. M. Joshi, who brought his extensive experience at Geneva to London, but also brought his nonradical, liberal discursive approach to worker's rights. ${ }^{80}$

Joshi made his case in repeatedly internationalist terms. At his plenary address on November 20, 1930, he insisted that the workers of India-though illiterate and ignorant-desired full self-government, in part due to the insufficiency of government efforts to tame the evils of industrialization. ${ }^{81}$ While ILO influence had led to some labor legislation, the influence of Indian and European industrialists had stymied the potential of these acts. Joshi therefore proposed a set of fundamental rights for workers, adult suffrage, and the retention of labor as a central or federal subject. While these were seemingly national-scale proposals, the latter, especially, was framed as a mechanism for continuing to connect Indian workers to the internationalist regulations of the ILO. Only if the federal center could ratify legislation for all of India, including the Princely States, could ILO conventions be transmitted to every worker. But Joshi also spoke out from the specifics of labor to the broader tone the RTC should adopt:

Lastly, may I say that to-day Labour is not the only matter which is internationally considered? The tendency to find an international solution to our difficulties is naturally, and very properly, growing and occupying a wide sphere, and I hope that our Constitution will be so framed in this Conference that India, as a whole, will be able to take full benefit of the international action, and India, as a whole, will also be able to be helpful in the international solution of the difficulties of the world. ${ }^{82}$

Joshi and his fellow labor representative Mr. Shiva Rao were, however, disappointed at the work of the first RTC sessions, which, they suggested, made the condition of workers in India not better, but worse-in no small part due to the failure to guarantee that provincial labor regulations would continue to adhere to those proposed by the ILO ${ }^{83}$ In the second session of the RTC, Joshi's comments focused more on internal labor rights than labor internationalism, while in the final session his only new pleas were for the representation of aboriginal and hill tribe people.

This failure to pursue a more radically internationalist vision was acerbically noted in the communist British newspaper the Daily Worker, who had hired Shapurji Saklatvala to cover the RTCs. After working in Indian industry, Saklatvala had come to London in connection with Indian Trade Unions before becoming associated with the Independent Labour Party and then the British Communist Party. Just after the second session of the RTC began, the Daily Worker dismissed the trivial talk of democracy and constitutional details by "N.M. Joshi, the imperialists' principal tame Indian labour leader" who had failed to advocate universal adult suffrage ${ }^{84}$ His internationalist and anticolonial credentials in question, Joshi's record at the conference ultimately blends in to those of the 
other delegates for whom the prime concerns remained those of (national) federal structure and minority agreement.

The pan-Islamism described above marked a political claim made on the basis of a religious diaspora-just one of many religious internationalisms, some of which relied on spiritually universalistic claims. As any history of world religion will show, in the earlymodern period trans-state and intercultural networks were pioneered by religious organizations. While many later supposedly secular international organizations retained the mark of religious origins (see the "Covenant" of the League of Nations), and others bridged the techno-scientific and the religious (see the Red Crescent and Red Cross), some branches of world religions transitioned successfully into "religious internationals" in the twentieth century. ${ }^{85}$

The Christian Church in India was the church of the majority of British civil servants and members of the military, and of roughly five million Indians. As the Indian Christians delegate at the first session of the RTC, Mr. K. T. Paul, explained during his plenary address on November 20, 1930, this put the church in a unique position. Religion connected Indian Christians to the West, and made them particularly conscious of the value to India of maintaining as many international connections as possible. While an historic connection, this was also felt to be part (akin to Joshi) of India's particularly current internationalist moment:

We are aware and proud of the fact that India, even as a so-called "subject nation," is becoming more and more an influence, through her literature and philosophy, and what I may call her spirit, upon the life and thought and spirit of many nations in both hemispheres ... We crave for our India a real place, not merely in the British Commonwealth, but also in the sisterhood of all nations, a place that is real and effective for the good of the entire world. ${ }^{86}$

This internationalist vision was, however, hemmed in by Paul's fears for the fate of Indian Christians within a constitution drafted in the heat of communal discord. While the comments above had come from the end of his speech, it had opened by insisting that together with the Indian Catholic representative, Mr. Pannir Selvam, Paul co-represented five million Indians. In an imaginative take on the census statistics, he claimed this was next to only the Muslims in terms of religious minority. ${ }^{87} \mathrm{He}$ then went on to make special claims for the unique contribution of Christians to the educational and medical professions, while the everyday Christian was more likely to be a worker than a landowner. The immediate political necessity for Indian Christians was not to emphasize their internationalism, but to obfuscate it beneath the claims of their nationalism:

In all such ways we are the servants of our Motherland and shall always feel proud to be servants of our Motherland. Though our religion has come from outside, and we derive from it our deepest and most powerful direction for our private and public life and relationships, it should be realised that we have been in India for I,700 years; that is, for over 700 years before the first Muslim arrivals in India. ${ }^{8}$

Paul proceeded to cite resolutions from the All-India Christian Council backing demands for dominion status, but the focus of his demands was for a strong federal state that could 
protect all minorities. Selvam did not play a large role in the RTC, but as part of his return journey he passed through Rome and pressed upon the British Legation to the Holy See, George Ogilvie-Forbes, to organize an audience for him with the pope. ${ }^{89}$ This took place on February 5, 1931, with a report on the conversations passed back to the Foreign Office in London. Ogilvie-Forbes was disappointed by the pope's discretion regarding his views on the RTC, but Sevlam was then interviewed by Cardinal Pacelli, the Vatican Secretary of State. Sevlam said that the Indian Catholic community should be pleased with the decision at the RTC to recognize their churches as Indian, not foreign institutions and, in principle, for Catholic schools to be maintained at government expense. Ogilvie-Forbes deduced from this conversation, and a dinner party he held for Sevlam that evening, that the Holy See was sympathetic to the RTC. While this may have been the case, it seems that for Indian Christians, including members of the Catholic (Universal) Church, the adopted tactic was to deny the internationalism of the church, in the hope of securing a place in the new national constitution.

Who, then, took up the charge of spiritual internationalism at the RTC? Gandhi would be the obvious advocate, eschewing religious communal identification in favor of spiritual unity across borders, beliefs, and territories. But this also, it seems, entailed transcending the political connotation of internationalism. Even this focus on overcoming nations, or working between them, may have been too much for a political ascetic whose commitment was to a universalistic humanitarianism. For Gandhi, some have argued, Indian nationalism was simply the most convenient first staging post for a universal attempt to save humankind. ${ }^{90}$

Gandhi had been willing to consider India existing as a self-governing part of the empire in the early I920s, but with the rise of the new, more radical generation of Congress activists, led by Nehru, dominion status was rejected. ${ }^{91}$ After the 1930 Imperial Conference and the resulting 193I Statute of Westminster offered a formal definition of what the new, modern dominions would be, it became equally clear to the British government that dominion status would be best dropped. As such, this international frame disappeared in preparation for a colonial federation that never came.

\section{Conclusions}

In reading the twentieth-century, Sluga and Clavin encourage us to reject simplistic categorizations of its internationalisms: "The historical point is that there cannot be a simple analytical division between good internationalism (whether pacifist or communist or liberal) and bad internationalism (whether communist, imperialist or neoliberal)."92 Similarly, Halliday did not condemn hegemonic (imperial) or radical (communist) internationalism; rather, he used them to question the moral claims of liberal internationalism. Likewise, I hope here to have complicated readings of the Round Table Conference that pose the British as heavy-handed imperial autocrats and Indian nationalists as radical anticolonialists. The liberal form of the international conference, modeled in part on the League of Nations, brought together both moderate and (some) extremist British and Indian delegates to debate India's international and imperial future. Dominion status, and the international, outward-looking agenda it implied, quickly slid from view, as federalism became the main topic of discussion. This was an initiative jointly devised by Indian nationalists and representatives of Princely India, but the conclusions of 
the RTC were widely interpreted as a failure for radical anticolonialists and a triumph for liberal (not die-hard) imperial internationalism, which would keep India within the British Empire not as a dominion but as, in all but name, a colony. But this particular iteration of imperial internationalism had undoubtedly been influenced by anticolonial (inter)nationalism, the liberal promise of League internationalism, and the ascendant form of the international conference, reworked here into the shape of a round table.

The Government of India Act (1935), which ultimately resulted from the RTC, created provincial autonomy for Indian elected ministries (akin to what had first been proposed by the Indian government in I9II) and dictated that federation would only be triggered when a set number of Princely States had voluntarily offered to federate. By the time of the Second World War they had not done so; Indian federation was therefore postponed until after the war and independence.

The RTC had sustained limited debates about dominion, pan-Islamic, labor and religious internationalism, but it ultimately marked a triumph of an imperial internationalism that managed to sustain the anomaly of India's international status while offering anti-colonial nationalists only further devolution and democratization at the provincial level. Congress eventually agreed to seek election to the new provincial ministries, scoring outstanding victories in the 1937 elections. The future governors of independent India secured their first direct experience of the art of statecraft in a state crafted at the RTC in London. While it may not have been a thoroughly internationalist space, the Round Table Conference was an informal international organization that further clarified the territorial and diplomatic anomaly of India. It made the Indian state and set the template for what, in 1947 , would become two of the world's newest, and one of the world's largest, democracies.

\section{NOTES}

The research was funded by the UK's Arts and Humanities Research Council (AH/Moo8I42/I) as part of the "Conferencing the International: A Cultural and Historical Geography of the Origins of Internationalism (1919-1939)" project. I would like to thank Jake Hodder and Mike Heffernan for their collaboration on this project, and I am indebted to Nehal Bhuta and Guy Fiti Sinclair for inviting me to the workshop from which this dossier arose, and for their patient editorial work. For comments on earlier drafts of the paper, I thank David Beckingham.

I. See S. Pedersen, The Guardians: The League of Nations and the Crisis of Empire (Oxford: Oxford University Press, 20I5); Guy Fiti Sinclair, To Reform the World: International Organizations and the Making of Modern States (Oxford: Oxford University Press, 20I7).

2. For instance, on January 22, 1919, Edwin Montagu, secretary of state for India, circulated an early draft of the Government of India Bill for comment to the British Delegation in Paris. The National Archives, CAB/ $24 / 73$.

3. Curzon admitted that he disliked the bill, but insisted to Montagu that he didn't have time to engage with it due to his other duties. See Robin J Moore, "Curzon and Indian Reform," Modern Asian Studies 27, no. 4 (October 1993): 719-740, 734.

4. Reginald Coupland, India: A Re-statement (Oxford: H. Milford, Oxford University Press, I945), I27.

5. Carl Bridge, Holding India to the Empire: the British Conservative Party and the I935 constitution (New Delhi: Sterling Publishers, 1986); R. J. Moore, The Crisis of Indian Unity, I9I7-I940 (Oxford: Clarendon Press, 1974).

6. Fred Halliday, "Three Concepts of Internationalism," International Affairs (Royal Institute of International Affairs 1944-) 64, no. 2 (Spring 1988): 187-198, 193. For a different interpretation of imperial internationalism, see Miguel Bandeira. Jerónimo, "A League of Empires: Imperial Political Imagination and Interwar Internationalists," in Internationalism, Imperialism and the Formation of the Contemporary World: The Pasts of the Present, ed. Miguel Bandeira Jerónimo and José Pedro Monteiro (Cham, Switzerland: Dordrecht Springer, 20I7), 87-I26, II3.

7. See Stephen Legg, “An International Anomaly? Sovereignty, the League of Nations, and India’s Princely 
Geographies," Journal of Historical Geography 43 (January 2014): 96-IIO; Thomas Metcalf, Imperial Connections: India in the Indian Ocean Arena, I860-I920 (Berkeley: University of California Press, 2007).

8. John Gallagher and Anil Seal, "Britain and India between the Wars," Modern Asian Studies I5, no. 3 (July 198I): 387-4I4; Metcalf, Imperial Connections.

9. Durba Ghosh and Dane Kennedy, eds., Decentring Empire: Britain, India and the Transcolonial World (London: Sangam Books, 2006); Ashwini Tambe and Harald Fischer-Tiné, eds., The Limits of British Colonial Control in South Asia: Spaces of Disorder in the Indian Ocean Region (Oxon, UK: Routledge, 2009).

Io. Mrinalini Sinha, Specters of Mother India: The Global Restructuring of an Empire (Durham, NC: Duke University Press, 2006); Kris Manjapra, Age of Entanglement: German and Indian Intellectuals across Empire (Harvard, MA: Harvard University Press, 20I4); Sunil S Amrith, Crossing the Bay of Bengal (Cambridge, MA: Harvard University Press, 2013); Reshaad Durgahee, “'Native' Villages, 'Coolie' Lines, and 'Free' Indian Settlements: The Geography of Indenture in Fiji,” South Asian Studies 33, no. I (2017).: 68-84.

II. Kris Manjapra, M.N. Roy: Marxism and Colonial Cosmopolitanism (Delhi: Routledge India, 20Io); Ole Birk Laursen, The Indian Revolutionary Movement in Europe, I905-19I8: Anticolonialism, Internationalism, and War (Liverpool: Liverpool University Press, forthcoming); Rehana Ahmed and Sumita Mukherjee, South Asian Resistances in Britain, I858-1947 (London: Bloomsbury Academic, 2012); Leela Gandhi, Affective Communities: Anticolonial Thought, Fin-de-siècle Radicalism, and the Politics of Friendship (Durham, NC: Duke University Press, 2005).

I2. Muhammad Ali Raza, Franziska Roy, and Benjamin Zachariah, preface to The Internationalist Moment: South Asia, Worlds, and World Views, 19I7-39, ed. Muhammad Ali Raza, Franziska Roy, and Benjamin Zachariah (London: SAGE, 2015), vii.

13. Muhammad Ali Raza, Franziska Roy, and Benjamin Zachariah, "Introduction: The Internatinalism of the Moment-South Asia and the Contours of the Interwar World," in The Internationalist Moment: South Asia, Worlds, and World Views, I9I7-39, ed. Muhammad Ali Raza, Franziska Roy, and Benjamin Zachariah (London; New Delhi: SAGE, 2015), xxiii.

I4. Manu Goswami, "Imaginary Futures and Colonial Internationalisms," The American. Historical Review II7, no. 5 (20I2): I46I.

I5. Ibid.

16. Pedersen, Guardians.

17. Alfred Zimmern, The Third British Empire: Being a Course of Lectures Delivered at Columbia University, New York (London: Oxford University Press, 1927); Stephen Legg, "Inter-war Spatial Chaos? Imperialism, Internationalism and the League of Nations," in Spatiality, Sovereignty and Carl Schmitt: Geographies of the Nomos, ed. Stephen Legg (London: Routledge, 20II), IO6-I24; Mrinalini Sinha, "Whatever Happened to the Third British Empire? Empire, Nation Redux," in Writing Imperial Histories, ed. A Thompson (Manchester: Manchester University Press, 2013), I68-183.

18. Erez Manela, The Wilsonian Moment: Self-Determination and the International Origins of Anticolonial Nationalism (Oxford: Oxford University Press, 2007); J. R. Martel, The Misinterpellated Subject (Duke, NC: Duke University Press, 2017).

i9. Halliday, "Three Concepts."

20. Also see Miguel Bandeira Jerónimo and José Pedro Monteiro, eds., Internationalism, Imperialism, and the Formation of the Contemporary World: The Pasts of the Present (Cham, Switzerland: Dordrecht Springer, 20I7).

2I. Andrew Muldoon, Empire, Politics, and the Creation of the 1935 India Act: Last Act of the Raj (Farnham, UK: Ashgate, 2009).

22. Moore, Crisis of Indian Unity.

23. Edward Thompson, "Notes of an Informal Address on the Political Prospect in India," Journal of The Royal Central Asian Society 19, no. 3 (I932): 49I-533.

24. Ruth Craggs and Martin Mahony, "The Geographies of the Conference: Knowledge, Performance and Protest," Geography Compass 8, no. 6 (June 20I4): 4I4-30.

25. Jake Hodder, Stephen Legg, and Mike Heffernan, "Introduction: Historical Geographies of Internationalism, 1900-1950,” Political Geography 49 (November 2015): I-6.

26. Legg, "An International Anomaly?"

27. Stephen Legg, "Of Scales, Networks and Assemblages: The League of Nations Apparatus and the Scalar Sovereignty of the Government of India," Transactions of the Institute of British Geographers NS 34, no. 2 (April 2009): 234-53; Legg, "An International Anomaly?"

28. Mark Mazower, Governing the World: The History of an Idea (London: Penguin Books Limited, 2012), 94.

29. Susan Pedersen, "Back to the League of Nations," The American Historical Review II2, no. 4 (October 2007): IO9I-II7.

30. Stephen Legg, "'The Life of Individuals as well as of Nations': International Law and the League of Nations' Anti-trafficking Governmentalities," Leiden Journal of International Law 25, no. 3 (September 20I2): 647-64.

31. On the International Labor Organization, see Sinclair, To Reform the World. 
32. Frederick Sherwood Dunn, The Practice and Procedure of International Conferences (Baltimore: John

Hopkins University Press, 1929), 5.

33. Ibid.

34. John Kendle, The Colonial and Imperial Conferences, I887-I9II: A Study in Imperial Organization

(London: Longmans, 1967).

35. "Twelve Years After: Armistice Day in Town and Country," The Times, November 12, I930.

36. British Library (henceforth BL), European Manuscripts E240/80: Papers of Sir Samuel Hoare, Secretary of State for India I93I-I935.

37. BL/India Office Records (henceforth IOR)/Q/RTC: collection guide.

38. BL/IOR/Q/RTC/58.

39. Government of India, Indian Round Table Conference: I2th November, I930-I9th January, I93I

(Calcutta: Government of India, Central Publications Branch, 1931), 4.

40. IOR/L/PJ/6/2008, File 313I.

4I. Legg, "An International Anomaly?"

42. Government of India, Indian Round Table Conference (Second Session) September 7, I93I- December I,

I93I Proceedings of Federal Structure Committee and Minorities Committee (Volume I) (Calcutta: Government of India Central Publications Branch, 1932), 167.

43. Ibid, I7.

44. Ibid, 48 .

45. Legg, "An International Anomaly?" IO3.

46. Nehru Memorial Museum and Library/BS Moonje Papers/Microfilm roll I (hereafter Moonje I).

47. Moonje I.

48. Ibid.

49. BL/Mss Eur E220/34: Hailey to Viceroy Irwin, January I, I93I.

50. Moonje I.

51. Gandhi was speaking on October 8, I931, in the Minorities Committee; see India, Indian Round Table

Conference (Second Session) September 7, I93I-December I, I93I, I345.

52. $\mathrm{BL} / \mathrm{IOR} / \mathrm{L} / \mathrm{PJ} / 7 / 2 \mathrm{I2}$.

53. Also see Harald Fischer-Tiné, "The Other Side of Internationalism: Switzerland as a Hub of Militant Anti-colonialism, c.1910-1920," in Colonial Switzerland: Rethinking Colonialism from the Margins, ed. Patricia Purtschert and Harald Fischer-Tiné (London: Palgrave Macmillan UK, 2015), 22I-258.

54. Carl Schmitt, Positionen und Begriffe: im Kampf mit Weimar_Genf_Versailles: 1923-I939, ed. Carl

Schmitt (Berlin Duncker \& Humboldt, I940 [1988]); Carol Miller, "Geneva—The Key to Equality: Inter-war

Feminists and the League of Nations," Women's History Review 3, no. 2 (1994): 219-45.

55. Madeleine Herren, "Geneva, I919-1945: The Spatialities of Public Internationalism and Global

Networks," in Mobilities of Knowledge, ed. Heike Jöns, Peter Meusburger, and Michael Heffernan (Cham,

Switzerland: Springer, 20I7), 2II-226.

56. The following information is drawn from Who Was Who (Oxford University Press, 20I4), the Oxford

Dictionary of National Biography (Oxford: Oxford University Press, 20I5), and the official guide to BL/IOR/Q/ RTC.

57. Dunn, Practice and Procedure of International Conferences.

58. Norman L Hill, The Public International Conference: Its Function, Organization and Procedure (Stanford: Stanford University Press, 1929).

59. League of Nations Photo Archive, accessed June Io, 2017, http://www.indiana.edu/ league/ conferencedata.htm.

6o. Bridge, Holding India to the Empire.

6. Dunn, Practice and Procedure of International Conferences, 189.

62. Hill, Public International Conference, 154.

63. Dunn, Practice and Procedure of International Conferences, 17, 202.

64. Ibid.

65. Ibid.

66. Dunn, Practice and Procedure of International Conferences, I89.

67. Quoted in R. P. Singh, "The Irwin Declaration of 1929: Its Background and Implications," Proceedings of the Indian History Congress 38 (1977): 460-468, 460.

68. Ibid.

69. See ibid.

70. India, Indian Round Table Conference: I2th November, I930-I9th January, I93I, I7.

7I. Glenda Sluga and Patricia Clavin, "Rethinking the History of Internationalism" in Internationalisms: $A$ Twentieth-Century History, ed. Glenda Sluga and Patricia Clavin (Cambridge: Cambridge University Press, 2016), 3-I6, II.

72. For classic accounts of the Indian experience, see Mushirul Hasan, ed., Communal and Pan-Islamic Trends in Colonial India (New Delhi: Manohar, 1981); and Gail Minault, The Khilafat Movement: Religious Symbolism and Political Mobilization in India (New York: Columbia University Press, 1982). 
73. India, Indian Round Table Conference (Second Session), 94.

74. Ibid.

75. BL/IOR/Mss Eur E220/34.

76. India, Indian Round Table Conference (Second Session), 92.

77. Khalid Ali, Ali Brothers: The Life and Times of Maulana Mohamed Ali and Shaukat Ali (Karachi: Royal Book Company, 2012), 787-92.

78. Patrizia Dogliani, "The Fate of Socialist Internationalism," in Internationalisms: A Twentieth-Century History, ed. Glenda Sluga and Patricia Clavin (Cambridge: Cambridge University Press, 2016), 38-6o.

79. Manjapra, M.N. Roy: Marxism and Colonial Cosmopolitanism.

8o. On the conjunction of liberal and socialist internationalism in the interwar period more broadly, see Daniel Laqua, "Democratic Politics and the League of Nations: The Labour and Socialist International as a Protagonist of Interwar Internationalism," Contemporary European History 24, no. 2 (May 2015): 175-92.

8I. India, Indian Round Table Conference: November I2, I930-January I9, I93I, I03.

82. Ibid, I05.

83. V. B. Karnik, N.M. Joshi: Servant of India (Bombay: United Asia Publications, 1972), I8I.

84. “'Democracy Bunk': Trivial Talk at Indian Round Table Conference,” Daily Worker, September I7, I93I.

85. On Jewish internationalism in particular, see Abigail Green, "Religious Internationalisms," in Internationalisms: A Twentieth-Century History, ed. Glenda Sluga and Patricia Clavin (Cambridge: Cambridge University Press, 2016), I7-37.

86. India, Indian Round Table Conference: November I2, I930-January I9, I93I, I3I.

87. The I93I Census put Hindus at circa 239 million, Muslims at seventy-seven million and Christians at six million. Christians by this listing were fewer than Buddhists, at twelve million, although these were often grouped with Hindus. Christians could thus be listed as the third largest religion in India, though they were seventy-one million fewer than the Muslims. They were outnumbered by the eight million "tribals," though for the church, if not the census, these groups presumably did not constitute a religion. See 193I Census of India, Volume I: India (Lahore: Civil and Military Gazette Press, I933), 387.

88. India, Indian Round Table Conference: November I2, I930-January I9, I93I, I29.

89. NA/Reforms/1931/39/3I-R.

90. Faisal Devji, The Impossible Indian: Gandhi and the Temptation of Violence (London: Hurst \& Co, 20I2).

9I. Rohit De, "Between Midnight and Republic: Theory and Practice of India's Dominion Status," International Journal of Constitutional Law I7, no. 4 (2019): I213-I234.

92. Sluga and Clavin, "Rethinking the History of Internationalism," Io. 